\title{
BONDING EFFICIENCY OF UNIVERSAL ADHESIVE TO DENTINE IN DIFFERENT ETCHING AND CURING MODES
}

\author{
Milan Miljković ${ }^{1}$, Stefan Dačić2, Goran Radenković3 ${ }^{3}$ Milica Jovanović ${ }^{4}$
}

\begin{abstract}
Adhesive bond strength and polymerization shrinkage are influenced by many different factors, including etching mode and light properties of a curing source. Different etching and curing techniques have been developed in an attempt to reduce polymerization shrinkage and stress development, thereby increasing the bond strength at the composite/dentine interface. The purpose of this study was to evaluate the influence of total-etch and self-etch mode as well as continuous and soft-start light curing mode on micro-tensile bond strength of bulkfill composite to dentine using universal adhesive. According to the etching and lightcuring mode applied, teeth were randomly divided into four different groups ( $n=15)$ : TC (total-etch, continuous mode), TS (total-etch, soft-start), SC (soft-start, continuous mode) and SS (selfetch, soft-start). Cylindric composite build-ups were made with 3M FiltekBulkfill Posterior. Specimens were subjected to micro tensile bond strength test in a universal testing machine at a crosshead speed of $0.5 \mathrm{~mm} / \mathrm{min}$. The failure force was recorded in Newton $(\mathrm{N})$ and calculated in MPa as a ratio of Newton to the surface of the bonded area. Data were analyzed using twoway ANOVA and Students t-test.Micro tensile bond strength was not affected by the lightcuring mode since no significant statistical difference was determined between the continuous and soft-start groups, irrespective of the etching mode used. On the other hand, micro tensile bond strength was highly influenced by the etching mode since significant statistical difference was determined between the total-etch and self-etch groups, irrespective of the lightcuring mode.
\end{abstract} Acta Medica Medianae 2020;59(2):60-65.

Key words: bond strength, universal adhesive, total-etch, self-etch, soft-start

${ }^{1}$ University of Niš, Faculty of Medicine, Research Center for Biomedicine, Niš, Serbia

${ }^{2}$ Clinic of Dentistry, Department for Restorative Dentistry and Endodontics, Niš, Serbia

${ }^{3}$ University of Niš, Faculty of Mechanical Engeneering,

Laboratory for testing materials and machinery, Niš, Serbia

${ }^{4}$ University of Kragujevac, Faculty of Medical Sciences,

Department of Dental Prosthetics, Kragujevac, Serbia

Contact: Milan Miljković

5/2 Maksim Gorki St., 18000 Niš, Serbia

E-mail: milandent89@yahoo.com

\section{Introduction}

Strong adhesive bond between the filling and cavity walls is mandatory for long-lasting composite restorations. To achieve a strong adhesive bond, proper clinical technique and tooth surface preparation is required (1). The quality of adhesive bond is usually determined by measuring micro tensile or shear bond strength to enamel or dentine. Achieving optimal adhesive bond to dentine is more complicated when compared to enamel, due to the presence of smear layer and histological differences between the two substrates (2).

In order to improve their clinical efficacy, the composition of dental adhesive systems is under constant development and new products are continuously introduced to the market. As a result, several generations of bonding agents are now available in the dental market with different number of bottles and their application technique (3). Multistep total-etch adhesives are still considered to be the gold standard in achieving a strong bond despite of their time-consuming and technique-sensitive application. On the other hand, self-etch adhesives have greatly simplified the adhesive application process since they do not require a separate acid etching step, rinsing and drying. These systems have gained a lot of popularity in the last few years because they are extremely easy to use and timesaving (4).

The most recently introduced adhesive system to the dental market is "universal" or "multimode" adhesive which can be applied in total-etch, self-etch, or selective-etch mode, as well as on different materials. The goal of this new adhesive system is to further simplify the bonding procedure and clinicians' decision making when considering bonding agents and adhesive techniques (5). 
However, universal adhesives have raised a lot of controversy regarding their bond strength and clinical performance. Manufacturers claim that optimal bond strength can be achieved regardless of the chosen application technique. The exact composition of new adhesives is never fully disclosed and information about the rate of shrinkage and hardness of adhesives after polymerization is very limited (6).

The purpose of this study was to evaluate the influence of different etching and light curing modes on the micro-tensile bond strength of universal adhesive to dentine. The following null hypotheses were tested in this study:

(1) etching mode will have no significant impact on micro tensile bond strength and there would be no significant difference between the total-etch and self-etch mode;

(2) light curing mode will have no significant impact on micro tensile bond strength and there would be no significant difference between the continuous and soft-start mode;

(3) etching and light curing mode interaction will have no significant impact on micro tensile bond strength.

\section{Materials and methods}

Sixty non-carious human teeth, extracted for periodontal, prosthetic and orthodontic purposes, were used in order to achieve the goal of this study. After extraction, the teeth were purified from blood and periodontal tissue detritus with a hard brush and stored in physiological saline at room temperature. In order to expose a flat dentine surface, teeth were sectioned in mesio-distal direction, parallel to their longitudinal axis, using low-speed diamond saw with water cooling. The exposed areas of dentine were then polished with silicone discs of different fineness (coarse, medium, fine). The smear layer from the exposed surface of dentine was removed by brush- ing with a soft brush under running water for 60s. Samples were then transferred to an ultrasonic bath at $25{ }^{\circ} \mathrm{C}$ for 45 minutes. In order to mimic the humid environment in the oral cavity, prepared samples were stored in distilled water at room temperature, before use. The obtained dentine plates were then deposited into cylindric molds and fixed with super-hard stone, class IV (Zhermack Elite Stone).

The teeth were randomly divided into four different groups ( $n=15$ ) based on the etching and light curing mode applied: TC (total-etch, continuous mode), TS (total-etch, soft-start mode), SC (selfetch, continuous mode) and SS (self-etch, soft-start mode). In groups TC and TS, the exposed surface of dentine was etched according to the manufacturer's instructions with $37 \%$ phosphoric acid for $15 \mathrm{~s}$. The acid was thoroughly rinsed with water-spray for $10 \mathrm{~s}$ and air-dried for 5s. 3M Universal Single Bond was then applied by micro brush for $5 \mathrm{~s}$ and mildly airdried for 5 s until a uniform glass-like dentine surface was obtained. The adhesive was then light cured for $10 \mathrm{~s}$ in the continuous or soft-start mode according to their respective groups, using Woodpecker Led-G lightcuring device. In groups SC and SS, the etching step was excluded, so the 3M Universal Single Bond was applied directly to the prepared dentine surface the same way as before. Cylindric composite buildups were made with3M FiltekBulkfill Posterior, using a plastic mold, $4 \mathrm{~mm}$ in diameter and $4 \mathrm{~mm}$ in height. Bulkfill composite was carefully packed in one layer and light cured in either continuous $\left(1200 \mathrm{~mW} / \mathrm{cm}^{2}\right.$ for $40 \mathrm{~s})$ or soft-start mode $\left(400 \mathrm{~mW} / \mathrm{cm}^{2}\right.$ for $10 \mathrm{~s}+$ $1200 \mathrm{~mW} / \mathrm{cm}^{2}$ for 30s) according to their respective groups. The distance between the tip of the light curing device and the surface of the specimens was minimal.Plastic molds were then removed and samples were stored in a water bath at $37^{\circ} \mathrm{C}$ before use. The materials used in this study are shown in Table 1.

Table 1. List of products used

\begin{tabular}{|c||c||c||}
\hline \multicolumn{1}{|c||}{ Product } & Manufacturer & Description \\
\hline \hline 3M Universal Single Bond & 3M ESPE (USA) & Universal adhesive \\
\hline 3M Etchant Gel & 3M ESPE (USA) & $37 \%$ Phosphoric acid \\
\hline 3M FiltekBulkfill Posterior & 3M ESPE (USA) & Composite material \\
\hline Zhermack Elite Stone & Zhermack (Germany) & Class IV stone \\
\hline
\end{tabular}

After 24 hours, specimens were subjected to micro tensile bond strength test in a universal testing machine (Wagezelle Load Cell, Hottinger Baldwin Messtechnik, Germany), at a crosshead speed of 0.5 $\mathrm{mm} / \mathrm{min}$. Specimens were secured in a metal base so that the bonded cylinder base was parallel to the shear force direction. The failure force was recorded in Newton (N) and calculated in MPa as a ratio of Newton to surface of the bonded area.
Statistical analysis was performed with SPSS soft-ware (version 23.0). Descriptive statistics, including the mean, standard deviation, minimum and maximum values were calculated for all groups.

Kolmogorov-Smirnov test was applied to confirm the normal distribution of the results. Two-way ANOVA (etching and light curing mode) and Students t-test were applied to determine whether significant differences in debond values existed 
among the groups. Significance for all statistical tests was predetermined at $\mathrm{p}<0.05$.

\section{Results}

Descriptive statistics of the microtensile bond strength of different groups is illustrated in Table 2. The highest average bond strength value was related to TC group and the lowest bond strength value was recorded in the SS group. KolmogorovSmirnov test found normal data distributions ( $p>$ 0.05). Two-way ANOVA (Table 3) indicated that there were statistically significant differences for the variable etching mode $(p=0.003)$, but failed to identify statistically significant differences for the variable light curing mode $(p=0.406)$ and any interaction between variables $(p=0.829)$. Students $t-$ test identified significant statistical difference between the groups that have been conditioned with acid and the untreated groups, in general (Table 4). Higher bond strength was obtained in groups TC and TS compared to SC and SS $(p<0.05)$. No significant statistical difference was determined between the continuous and soft-start groups, in general (Table 5). Higher bond strength was obtained in groups TC and SC compared to TS and SS ( $p<$ 0.05).

Table 2. Descriptive statistics (in MPa) of microtensile bond strengths of the 4 subgroups tested

\begin{tabular}{||l|c|c|c||}
\cline { 2 - 4 } \multicolumn{1}{c|}{} & Mean \pm SD & Min & Max \\
\hline TC & $28.2 \pm 7.2$ & 18.3 & 41 \\
\hline TS & $26.6 \pm 6.6$ & 17.9 & 37.9 \\
\hline SC & $23.1 \pm 4$ & 18.7 & 31 \\
\hline SS & $22.2 \pm 5.1$ & 14.2 & 30.5 \\
\hline
\end{tabular}

TC (total-etch,continuous); SC (self-etch,continuous);

TS (total-etch,soft-start); SS (self-etch, soft-start)

Table 3. Two-way analysis of variance

\begin{tabular}{|l|c|c|c|c|c||}
\cline { 2 - 6 } \multicolumn{1}{c|}{} & Sum of Squares & Df & Mean Squares & F & Sig \\
\hline Etching mode & 332.762 & 1 & 332.762 & 9.644 & $\mathbf{0 . 0 0 3 *}$ \\
\hline Curing mode & 24.193 & 1 & 24.193 & 0.701 & 0.406 \\
\hline Interaction & 1.633 & 1 & 1.633 & 0.047 & 0.829 \\
\hline
\end{tabular}

*Statistical significance at the level of 5\%. Df-degrees of freedom.

Table 4. Statistical comparison between the total-etch and self-etch groups

\begin{tabular}{|l||c||c|c|}
\cline { 2 - 3 } \multicolumn{1}{c||}{} & Mean $\mathbf{\text { SD }}$ & t & p \\
\hline TC \& TS & $27.4 \pm 6.8$ & $\mathbf{0 . 0 0 9 *}$ & 0.05 \\
\hline SC \& SS & $22.7 \pm 4.5$ & & \\
\hline
\end{tabular}

*Statistical significance at the level of $5 \%$.

Table 5. Statistical comparison between the continuous and soft-start groups

\begin{tabular}{|l||c||c|c|}
\cline { 2 - 4 } \multicolumn{1}{c||}{} & Mean \pm SD & t & p \\
\hline TC \& SC & $25.7 \pm 6.3$ & 0.955 & 0.05 \\
\hline TS \& SS & $24.4 \pm 6.2$ & & \\
\hline
\end{tabular}




\section{Discussion}

Bond strength depends on a number of different factors, such as etching mode, light curing mode, composite resin type, filling technique, cavity shape and size. Previous research suggest that etching mode has the greatest impact on micro tensile bond strength (7). Curing mode may also significantly affect bond strength by regulating the degree of polymerization shrinkage which can be transferred to the bonding interface in the form of debonding tensile forces. Soft-start is a modified, two-step light curing mode which uses an initial lowlight intensity to minimize the stress generated during polymerization, followed by a higher light intensity to provide proper mechanical properties (8). It has been previously reported that by slowing down the conversion in initial phase, negative effects of polymerization shrinkage and stress development on adhesive bond strength can be reduced at least to some extent (9).Thus light intensity and soft-start mode also affect the resin monomer penetrating the dentin collagen fiber network in forming the hybrid layer, thereby influencing the dentin bond performance (10).

The first null hypothesis of this study was rejected. Two-way ANOVA showed that the micro tensile bond strength is highly technique-dependent. Student's t-test also confirmed that there was a significant difference between the total-etch and self-etch groups, irrespective of the curing mode. Significantly higher bond strength was determined in TC and TS groups probably due to the formation of porosities in the dentine surface and penetration of resin into the porosities. Our findings are in line with those of previous studies conducted by Pouyanfaret al. which indicate that cavity treatment with phosphoric acid significantly increases the microretential surface and enables the formation of a thick hybrid layer $(5-50 \mu \mathrm{m})(11)$. On the other hand, self-etch adhesive systems cause partial and superficial demineralization of the smear layer and dentin because of the presence of weaker acidic primers. Since demineralization depth depends on the $\mathrm{pH}$ of the acid monomer, hybrid layer formed in self-etch mode is much thinner $(5-8 \mu \mathrm{m})(12)$. In a study conducted by Manfroi et al. SEM analysis revealed apparent morphological differences in the bond interface between the total-etch and self-etch adhesive systems. It can be concluded that although eliminating the etch and rinse step may simplify the process of adhesive application, it does not necessarily result in higher clinical success rate (13).

The second null hypothesis of this study was accepted. Two-way ANOVA showed that the micro tensile bond strength is not light-dependent.

Student's t-test confirmed there was no significant difference between the continuous and soft-start groups, irrespective of the etching mode. Results of previous studies researching modified light curing protocols are contradictory, so opinions of the scientific community on the matter are divided (14). Also, there is still no agreement about the ideal light intensity in the initial phase of soft-start mode (15). Too high or too low initial intensity cannot achieve a good curing effect, so we used initial light intensity of $400 \mathrm{~mW} / \mathrm{cm}^{2}$ in our experiment. In theory, softstart should provide significant benefits to bond strength by reducing the degree of polymerization shrinkage and stress development (16). However, the results of our in vitro study revealed no significant influence of soft-start mode on bond strength. Moreover, higher values of micro tensile bond strength were determined when continuous mode was used. Thus, the benefits of soft-start light curing still remain questionable and further research is required to determine the relationship between light transmission and adhesive bond strength (17).

The third null hypothesis of this study was accepted. Interaction between the etching and curing mode had no significant impact on micro tensile bond strength. Important limitation of this study was that no thermal cycling or artificial aging was performed to better simulate clinical conditions.

\section{Conclusion}

According to the methodology employed and based on the obtained results, it can be concluded that micro tensile bond strength of universal adhesive to dentine was significantly affected by the etching mode. Higher bond strength was determined in total-etch mode, irrespective of the curing mode applied. Micro tensile bond strength of universal adhesive was not affected by the curing mode.

\section{Acknowledgment}

This study was supported by the Ministry of Education, Science and Technological Development of the Republic of Serbia (project number 41018). 


\section{References}

1. Muñoz MA, Luque-Martinez I, Malaquias $P$, Hass $V$, Reis $\mathrm{A}$, Campanha $\mathrm{NH}$, et al. In vitro longevity of bonding properties of universal adhesives to dentin. Oper Dent 2015;40(3):282-92. [CrossRef][PubMed]

2. Sofan E, Sofan A, Palaia G, Tenore G, Romeo U, Migliau G. Classification review of dental adhesive systems: from the IV generation to the universal type. Ann Stomatol (Roma) 2017;8(1):1-17. [CrossRef][PubMed]

3. Bedran-Russo A, Leme-Kraus AA, Vidal CMP, Teixeira EC. An Overview of Dental Adhesive Systems and the Dynamic Tooth-Adhesive Interface. Dent Clin North Am 2017; 61(4): 713-31. [CrossRef][PubMed]

4. Giannini M, Makishi $P$, Ayres AP, Vermelho PM, Fronza BM, Nikaido T, et al. Self-etch adhesive systems: a literature review. Braz Dent J 2015;26(1):3-10. [CrossRef][PubMed]

5. Matos AB, Trevelin LT, Silva BTFD, Francisconi-DosRios LF, Siriani LK, Cardoso MV. Bonding efficiency and durability: current possibilities. Braz Oral Res 2017;31(1):e57. [CrossRef][PubMed]

6. Rosa WL, Piva E, Silva AF. Bond strength of universal adhesives: A systematic review and meta-analysis. J Dent 2015;43(7): 765-76. [CrossRef][PubMed]

7. Takamizawa T, Barkmeier WW, Tsujimoto A, Berry TP, Watanabe $H$, Erickson $R L$, et al. Influence of different etching modes on bond strength and fatigue strength to dentin using universal adhesive systems. Dent Mater 2016;32(2):e9-21. [CrossRef][PubMed]

8. Münchow EA, Meereis CTW, de Oliveira da Rosa WL, da Silva AF, Piva E. Polymerization shrinkage stress of resin-based dental materials: A systematic review and meta-analyses of technique protocol and photo-activation strategies. J Mech Behav Biomed Mater 2018; 82:77-86. [CrossRef][PubMed]

9. Tauböck TT, Feilzer AJ, Buchalla W, Kleverlaan CJ, Krejci I, Attin T. Effect of modulated photo-activation on polymerization shrinkage behavior of dental restorative resin composites. Eur J Oral Sci 2014;122(4): 293-302. [CrossRef][PubMed]
10. Li MZ, Wang JR, Liu H, Wang X, Gan K, Liu XJ, et al. Effects of light curing modes and ethanol-wet bonding on dentin bonding properties. J Zhejiang Univ Sci B 2016;17(9):703-11. [CrossRef][PubMed]

11. Pouyanfar H, Tabaii ES, Aghazadeh S, Nobari SPTN, Imani MM. Microtensile Bond Strength of Composite to Enamel Using Universal Adhesive with/without Acid Etching Compared To Etch and Rinse and Self-Etch Bonding Agents. Open Access Maced J Med Sci 2018; 6(11):2186-92. [CrossRef][PubMed]

12. Dačić $S$, Mitić $A$, Popović J, Simonović-Dačić $D$, Igić $M$. Ultrastructure of adhesive bond of composite to dentin. Acta Fac Med Naiss 2014;31(1):67-73. [CrossRef]

13. Manfroi FB, Marcondes ML, Somacal DC, Borges GA, Júnior LH, Spohr AM. Bond Strength of a Novel One Bottle Multi-mode Adhesive to Human Dentin After Six Months of Storage. Open Dent J 2016;10:268-77. [CrossRef][PubMed]

14. Dall'Magro $E$, Sinhoreti MA, Correr AB, CorrerSobrinho L, Consani S, Puppin-Rontani RM. Effect of different initial light intensity by the soft-start photoactivation on the bond strength and Knoop hardness of a dental composite. Braz Dent J 2007;18(2):10712. [CrossRef][PubMed]

15. Soares CJ, Faria-E-Silva AL, Rodrigues MP, Vilela ABF, Pfeifer CS, Tantbirojn D, et al. Polymerization shrinkage stress of composite resins and resin cements - What do we need to know? Braz Oral Res 2017;31(1):49-63. [CrossRef][PubMed]

16. Kim RJ, Kim YJ, Choi NS, Lee IB. Polymerization shrinkage, modulus, and shrinkage stress related to tooth-restoration interfacial debonding in bulk-fill composites. J Dent 2015;43(4):430-9.

[CrossRef][PubMed]

17. Steiner R, Edelhoff D, Stawarczyk B, Dumfahrt $H_{\text {, }}$ Lente I. Effect of dentin bonding agents, various resin composites and curing modes on bond strength to human dentin. Materials 2019;12(20):3395.

[CrossRef][PubMed] 


\title{
EFIKASNOST VEZIVANJA UNIVERZALNOG ADHEZIVA ZA DENTIN PRIMENOM RAZLIČITIH ADHEZIVNIH I SVETLOSNOPOLIMERIZUJUĆIH TEHNIKA
}

\author{
Milan Miljković1, Stefan Dačić ${ }^{2}$, Goran Radenković3, Milica Jovanović4 \\ ${ }^{1}$ Univerzitet u Nišu, Medicinski fakultet, Istraživački centar za biomedicinu, Niš, Srbija \\ ${ }^{2}$ Klinika za stomatologiju, Odeljenje za bolesti zuba i endodonciju, Niš, Srbija \\ 3Univerzitet u Nišu, Mašinski fakultet, Laboratorija za ispitivanje materijala i mašina, Niš, Srbija \\ ${ }^{4}$ Univerzitet u Kragujevcu, Fakultet medicinskih nauka, Odeljenje za stomatološku protetiku, \\ Kragujevac, Srbija
}

Kontakt: Milan Miljković

Maksima Gorkog 5/2,18000 Niš, Srbija

E-mail: milandent89@yahoo.com

$\mathrm{Na}$ jačinu adhezivne veze i polimerizacionu kontrakciju utiču mnogi različiti faktori, uključujući tehniku nagrizanja i svetlosna svojstva izvora za polimerizaciju. Vremenom su razvijene različite tehnike adhezije i svetlosne polimerizcije, u cilju redukcije polimerizacione kontrakcije i razvoja stresa, čime se povećava jačina adhezivne veze na spoju kompozit dentin.

Cilj ove studije bila je procena uticaja totalnonagrizajuće i samonagrizajuće tehnike, kao i kontinuiranog i rastućeg svetlosnopolimerizujućeg režima na jačinu adhezivne veze kompozita za dentin, primenom univerzalnog adhezivnog sistema.

Na osnovu primenjene tehnike nagrizanja i svetlosnopolimerizujućeg režima, uzorci su nasumično podeljeni u 4 grupe $(n=15)$ : TC (totalnonagrizanje, kontinuirani režim), TS (totalnonagrizanje, rastući režim), SC (samonagrizanje, kontinuirani režim) i SS (samonagrizanje, rastući režim).

Cilindrične kompozitne nadogradnje napravljene su od 3M FiltekBulkfill Posterior. Uzorci su podvrgnuti testiranju jačine adhezivne veze mikrozatezanjem u univerzalnoj mašini za testiranje, pri brzini pomeranja od $0,5 \mathrm{~mm} / \mathrm{min}$. Sila pucanja detektovana je u Njutnima (N) i preračunata u megapaskale (MPa), kao odnos Njutna prema površini bonding regije. Podaci su analizirani testom Two-way ANOVA i Studentovim t-testom. Režim svetlosne polimerizacije nije uticao na jačinu adhezivne veze, pošto nije utvrđena statistički značajna razlika između kontinuiranih i rastućih grupa, nezavisno od primenjene tehnike nagrizanja. Sa druge strane, jačina adhezivne veze u velikoj meri zavisi od tehnike nagrizanja, pošto je utvrđena statistički značajna razlika između totalnonagrizajućih i samonagrizajućih grupa, nezavisno od režima svetlosne polimerizacije.

Acta Medica Medianae 2020;59(2):60-65.

Ključne reči: čvrstoća vezivanja, univerzalno lepilo, totalnonagrizanje, samonagrizanje, meko pokretanje 